\title{
労働災害による頢顔面損傷患者の咀偁障害の評価に関する研究
}

\author{
中 島 博 ·松 浦 正 朗・岡田とし江*
}

\section{Assessment of masticatory disturbances in patients with occupational maxillofacial injuries}

\author{
Hiroshi NaKajima $\cdot$ Masaroh MatsuURA $\cdot$ Toshie OKadA ${ }^{*}$
}

\begin{abstract}
This study was designed to investigate masticatory disturbances in patients with occupational maxillofacial injuries. During the 3 -year 3 -month period from April 1992 through June 1995, 51 patients were examined on the basis of (1) dental findings, (2) mandibular mobility, ( 3 ) electromyograms (EMG), (4) occlusal findings by Dental Prescale ${ }^{\circledR}$, and ( 5 ) masticatory efficiency rate calculated from the results of a questionnaire that assessed the ability to chew 173 foods.

The following results were obtained:

1. Masticatory efficiency rate could be estimated on the basis of occlusal variables assessed with Dental Prescale ${ }^{\circledR}$. The most important occlusal variable with this method was maximal force.

2 . At a value of $40 \%$ or more, masticatory efficiency rate was correlated with dental findings and mandibular mobility.

3 . In this same group of patients, masticatory efficiency rate was correlated with electromyographic findings (silent period rate, etc.).

4. Variables of the occlusion evaluated with Dental Prescale ${ }^{\circledR}$ were positively correlated with masticatory efficiency rate.

5 . In patients with a masticatory efficiency rate of $40 \%$ or more, masticatory disturbances could be generally estimated from masticatory efficiency rate.

6. Many patients with a masticatory efficiency rate of less than $40 \%$ had lack of consistency between objective and subjective findings. Masticatory disturbances could therefore not be evaluated correctly by analyzing items ( 1$)$ to $(5)$ in this group of patients.
\end{abstract}

Key words: masticatory disturbance (咀喻障害), occupational injury (労働災害), maxillofacial trauma（顎顔面外傷）

鶴見大学歯学部口腔外科学第一講座

(主任 : 瀬戸晥一教授)

*労働福祉事業団関東労災病院歯科口腔外科

(主任 : 岡田とし江部長)

First Department of Oral and Maxillofacial Surgery, School of Dentistry, Tsurumi University (Chief: Prof. Kanichi Seto)

*Department of Oral Surgery, Rodofukushijigyodan Kanto Rosai Hospital (Chief: Toshie Okada) 受付日 : 平成 8 年 2 月 16 日
緒言 言

労働災害患者の「口の障害」の等級認定基準では, 咀嚼障害を,「そしゃく機能を廃したもの」「そしゃく 機能に著しい障害を残すもの」「そしゃく機能に障害 を残すもの」の三段階に区分し，歯の障害を，喪失お よび著しい損傷を受けた歯数により五段階に区分して いる（表 1 ).しかし，等級認定基準には「そしゃく機 能の障害は，上下咬合および排列状態ならびに下顎の 
表 1 口の障害認定基準

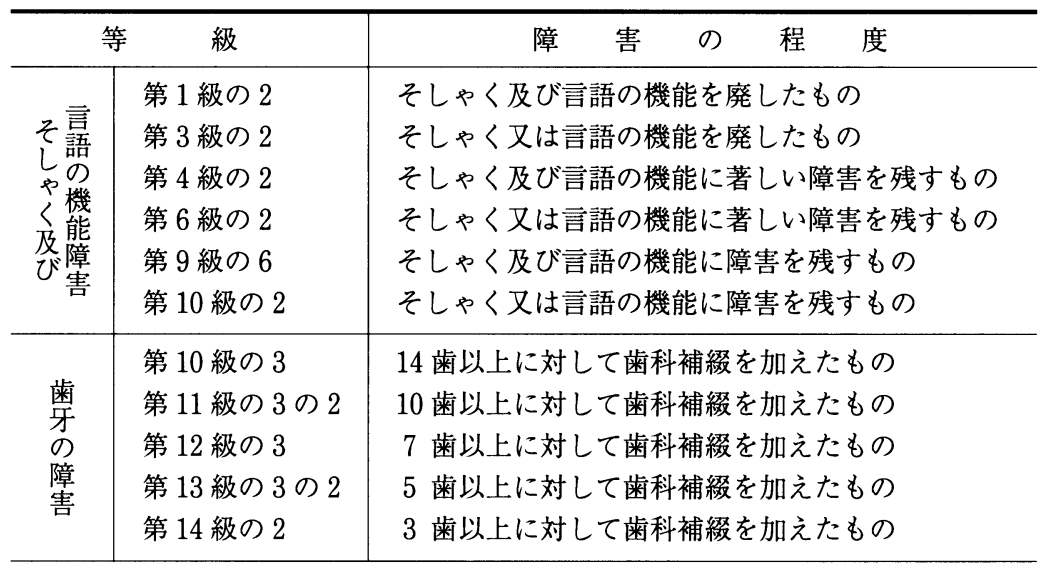

「労災補償 障害認定必携 1 )」より

開閉運動等により総合的に判断する」 ${ }^{1)}$ と記 載されているが, 咀嚼障害についての具体的な 評価方法や, 歯の障害との関連については言及 されていない. 著者は, 労働災害により歯や顎 骨に損傷を受けた患者の, 咀嚼障害の程度に関 する簡便で明確な評価方法を作成する目的で, 歯の所見, 下顎運動所見, 咀嚼筋筋電図所見, 咬合所見を調查し, これらと実際の患者の食品 咀嚼能力を数量化した咀嚼可能率との関係を 検討した。
表 2 対象症例 51 例の障害内容

\begin{tabular}{|c|c|c|c|c|}
\hline \multirow{2}{*}{ 傷 病 } & \multirow{2}{*}{ 名 } & \multicolumn{3}{|c|}{ 併 発 症 } \\
\hline & & 顎関節損傷 & 軟組織損傷 & 三叉神経損傷 \\
\hline 上下顎骨骨折 & 9 例 & 7 例 & 9 例 & 5 例 \\
\hline 上顎骨骨折 & 6 例 & 1 例 & 5 例 & 3 例 \\
\hline 下顎骨骨折 & 12 例 & 11 例 & 10 例 & 4 例 \\
\hline 歯槽骨骨折 & 9 例 & 1 例 & 4 例 & 1 例 \\
\hline 歯の岥失 & 10 例 & 2 例 & 5 例 & 2 例 \\
\hline 歯の損傷 & 5 例 & 0 例 & 3 例 & 1 例 \\
\hline & 尌 51 例 & 計 22 例 & 計 36 例 & 計 16 例 \\
\hline
\end{tabular}

\section{対象と方法}

対象患者は, 1992 年 4 月から 1995 年 6 月までに, 関 東労災病院歯科口腔外科に労働災害 (以下労災と略す) による障害に対する意見書作成を請求してきた 51 名 である.これらの患者はいずれも傷病治療が終了し, 症状固定と判断されたもので, 男性 44 名, 女性 7 名, 平均年齢は 43.6 歳（19～74 歳）であった.

対象の主たる傷病別症例数は, 顎骨骨折 27 例, 歯槽 骨骨折 9 例，歯の坆失 10 例，歯の損傷 5 例であった. 顎骨骨折の部位別内訳は, 下顎骨骨折 12 例, 上顎骨骨 折 6 例, 上下顎骨骨折 9 例であった. 顎骨骨折症例の 合併症としては, 歯の損傷 22 例, 顎関節損傷 19 例, 顔 面軟組織損傷 24 例, 三叉神経損傷が 12 例に認められ た. 対象例全体では顎関節損傷は 22 例で, その内訳は 関節突起骨折 11 例, 頡関節挫傷 11 例であった. 歯の 㲑失および損傷は 46 例で，その部位は前歯部 15 例， 臼歯部 7 例, 前歯部と臼歯部にわたるもの 24 例であっ た. 歯の咬合痛が後遺していたものは 8 例であった. 他の顎口腔領域の併発症としては顔面軟組織損傷 36 例, 三叉神経損傷 16 例および顔面神経損傷が 3 例に
認められた（表 2 ). 受傷部位の左右別では両側性のも の 41 例, 片側性のもの 10 例であった. 顎口腔領域以 外の合併損傷は, 対象 51 例中 26 例に認め, その内訳 は延べ症例数で頭部外傷 12 例, 四肢外傷 16 例, 眼外 傷 7 例, 骨盤骨折 4 例, 胸部外傷 2 例, 腹部外傷 1 例で あった.なお, 検査時に有床義歯を装着していたもの は 24 名であった。

これらの症例に対し以下の項目について調査し,こ の結果について $\mathrm{t}$ 検定および多変量解析を行い統計学 的に検討した。

\section{1. 歯の所見}

\section{(1) 欠損歯数と大臼歯咬合歯数}

労災受傷時の亦失のみでなく, 既存の欠損も含めた 全体の欠損歯数㧍よび第一, 第二大臼歯の欠損歯数抒 よび咬合歯数を調査した. 第一, 第二大臼歯の咬合歯 数の調査では, 咬合歯数は一歯対二歯咬合は一歯咬合 とし, 固定性橋義歯の橋体は除外した.

(2) Eichner 分類 ${ }^{2)}$

対象例を Eichner 分類で分類した. 本分類は, 歯列 
を前歯部, 左右小臼歯部, 左右大臼歯部 の 5 か所の咬合支持域に区分し，咬合支 持域の数により咬合状態を以下のよう に分類するものである.

$\mathrm{A}$ ：兒歯部 4 か所の咬合支持のあるもの

$\mathrm{B}$ : 臼歯部 4 か所の咬合支持のないもの

B-1 3 3 所の咬合支持のあるもの

B-2 2 か所の咬合支持のあるもの

B-3 1 か所の咬合支持のあるもの

B-4 前歯のみで咬合支持するもの

$\mathrm{C}:$ 咬合支持のないもの

すなわち C に近づくにしたがい咬合 関係が保たれていないことになる。

(3) 歯の抵抗得点

ブリッジの適応症と設計 3 ) に示され た，ブリッジの支台歯としての負担能力 を評価するために個々の歯の歯根膜表 面積から算出された指数を, 咬合に関与する第三大臼 歯も含め合計し, 歯の抵抗得点とした.

\section{2. 下顎運動所見}

(1) 最大開口量

最大開口時の上顎中切歯近心隅角間中点と切歯点の 距離を最大開口量とし測定した。

（2）側方限界運動量

側方咬合時の上顎中切歯近心隅角間中点を通る垂線 と切歯点の距離を側方限界運動量 ${ }^{4)}$ とし測定した.

\section{3 . 咀嗳筋筋電図所見}

同一歯科診療椅子で, Occluso Master ${ }^{\circledR}$ (TME$300 \mathrm{~K}$ 型一藤栄電気社製) を用い, 両側側頭筋前縁部沶 よび咬笳付着部に双極表面電極を貼付し，患者の最も 行いやすい任意の開口量にて, 咬合音の聴取が可能な 強度でのタッピング運動を行わせ，以下の項目を計測 した。

\section{(1) タッピング可能回数}

タッピング頻度を毎秒 $1 ， 2$ および 3 回に規定し， 10 秒間タッピング運動を行わせ, 実際に行えたタッピ ング回数を計測した.

(2) silent period (以下 $\mathrm{sp}$ と略す) の出現率

タッピング頻度を毎秒 $1 ， 2$ および 3 回に規定した 時, ならびに患者の行いやすい任意の頻度でのタッピ ング運動をさせた時の sp の出現率を計測した.

4. デンタルプレスケール ${ }^{\circledR} 30 \mathrm{HR}$ タイプおよび $50 \mathrm{HR}$ タイプ（以下それぞれ $30 \mathrm{H}$ および $50 \mathrm{H}$ と略すー 富士写真フィルム社製) による咬合所見

(1) $30 \mathrm{H}$ (測定範囲 $3 \sim 13 \mathrm{MPa}$ ) と ( 2 ) $50 \mathrm{H}$ （測 定範囲 $5 \sim 120 \mathrm{MPa}$ ）で，患者の中心咬合位での歯列 全体の接触面積 (発色部位の面積), 平均咬合力 $\left(0.0625 \mathrm{~mm}^{2}\right.$ 毎の咬合力の平均値), 最大咬合力 $\left(0.0625 \mathrm{~mm}^{2}\right.$ 毎の咬合力の最大值), 総咬合力 $(0.0625$ $\mathrm{mm}^{2}$ 毎の咬合力の積分值), 有効率 $\left(0.0625 \mathrm{~mm}^{2}\right.$ 毎の
表 3 労災患者の歯の所見

\begin{tabular}{|c|c|c|c|c|c|c|}
\hline 本 & \multicolumn{2}{|c|}{ 1-6 本 } & \multicolumn{2}{|c|}{ 7-12 本 } & $13-18$ 本 & 19-24 本 \\
\hline & \multicolumn{2}{|c|}{26} & \multicolumn{2}{|c|}{14} & 3 & 3 \\
\hline 本 & \multicolumn{2}{|c|}{1,2 本 } & \multicolumn{2}{|c|}{3,4 本 } & 5,6 本 & 7,8 本 \\
\hline & \multicolumn{2}{|c|}{15} & \multicolumn{2}{|c|}{9} & 3 & 4 \\
\hline 艾 & \multicolumn{2}{|c|}{3 歯咬合 } & \multicolumn{2}{|c|}{2 歯咬合 } & 1 歯咬合 & 0 歯咬合 \\
\hline & \multicolumn{2}{|c|}{7} & \multicolumn{2}{|c|}{9} & 7 & 8 \\
\hline \multicolumn{2}{|c|}{$B-1$} & \multicolumn{2}{|c|}{ B-2 } & $\mathrm{B}-3$ & B -4 & C \\
\hline \multicolumn{2}{|r|}{9} & 1 & & 5 & 1 & 5 \\
\hline \multicolumn{2}{|c|}{00 以上 } & \multicolumn{3}{|c|}{$99 \sim 50$} & \multicolumn{2}{|c|}{$49 \sim 0$} \\
\hline \multicolumn{2}{|c|}{24} & \multicolumn{3}{|c|}{24} & \multicolumn{2}{|r|}{3} \\
\hline
\end{tabular}

発色部位の咬合力のうち測定範囲におさまる割合）お よび接触面積と総咬合力の左右側別の割合を測定した. 対照として, 顎機能異常および歯の欠損がなく，大臼 歯に歯冠補緅が行われていない男女各 6 名を被験者と して労災患者と同一項目を同一方法で測定した。

測定方法は被験者を同一歯科診療椅子に咬合平面が 水平となるように坐らせ，中心咬合位で $30 \mathrm{H}$ および $50 \mathrm{H}$ それぞれ 3 枚を強く咬ませ, OCCLUZER ${ }^{\circledR}$ VER. 2.10 (FPD703-富士写真フィルム社製) で解析し, その平均值を算出した。

\section{5 . 咀嚼可能率}

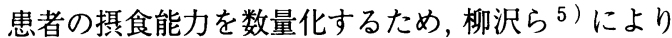
測定された食品テクスチャーの最も小さいランク 1 か ら最も大きいランク 10 までの 10 段階にランク分けさ れた 173 食品について, 患者が咀嚼可能か否かを問診 調査した. 173 品目から患者が食べたことのない食品 および嫌いな食品を除いた全品目数に対する，容易に 食べられる食品数の割合を算出し，これを各患者の咀 嚼可能率とした.この咀嚼可能率を 5 段階に区分し， $100 \%$ 以下 $80 \%$ 以上を咀嚼可能率 I（以下可能率 I と 略す), $80 \%$ 未満 $60 \%$ 以上を咀嚼可能率 II（以下可能 率 II と略す), $60 \%$ 未満 $40 \%$ 以上を咀嚼可能率 III（以 下可能率 III と略す), $40 \%$ 未満 $20 \%$ 以上を咀嚼可能率 IV (以下可能率 IV と略す), $20 \%$ 未満を咀嚼可能率 V （以下可能率 $\mathrm{V}$ と略す）とした.

結果

\section{1. 歯の所見 (表 3 )}

(1) 保歯数と大臼歯咬合歯数

欠損歯数は, 平均 6.7 本 $(0 \sim 24$ 本 $)$ であった. 上下 左右第一, 第二大臼歯のいずれかに欠損を認めた症例 は 51 例中 31 例で, その平均欠損数は 1.9 本 $(1 \sim 8$ 本) 
表 4 労災患者の下顎運動の所見

\begin{tabular}{c|c|c|c|c}
\hline \multirow{2}{*}{$\begin{array}{c}\text { 最大 } \\
\text { 開口量 } \\
(\mathrm{mm})\end{array}$} & \multicolumn{3}{|c}{ 平均 $43.2 \mathrm{~mm}(28 \sim 58 \mathrm{~mm})$} \\
\cline { 2 - 4 } & $29 \mathrm{~mm}$ 以下 & $30 \sim 35 \mathrm{~mm}$ & $35 \sim 40 \mathrm{~mm}$ & $40 \mathrm{~mm}$ 以上 \\
\cline { 2 - 4 } & 3 & 2 & 7 & 39 \\
\hline $\begin{array}{c}\text { 右側限界 } \\
\begin{array}{c}\text { 運動量 } \\
(\mathrm{mm})\end{array}\end{array}$ & \multicolumn{2}{|c}{ 平均 $8.1 \mathrm{~mm}(0 \sim 10 \mathrm{~mm})$} \\
\cline { 2 - 4 } & $7 \mathrm{~mm}$ 未満 & $7 \mathrm{~mm}$ 以上 \\
\hline $\begin{array}{c}\text { 左側限界 } \\
\text { 運動量 } \\
(\mathrm{mm})\end{array}$ & \multicolumn{2}{|c|}{11} & 40 \\
\cline { 2 - 4 } & $7 \mathrm{~mm}$ 未满 & $7 \mathrm{~mm}$ 以上 \\
\cline { 2 - 4 } & \multicolumn{2}{|c|}{10} & $41 \mathrm{~mm}(2 \sim 12 \mathrm{~mm})$ \\
\hline
\end{tabular}

であった. 第一，第二大臼歯の咬合歯数は，4歯が咬 合するもの 20 例， 3 歯が咬合するもの 7 例， 2 歯が咬 合するもの 9 例, 1 歯が咬合するもの 7 例, 咬合関係 のないもの8例であった. 咬合に関与する第三大臼歯 が存在した症例は 27 例であった。

(2) Eichner 分類

$\mathrm{A}$ が 30 例, B -1 が 9 例, B -2 が 1 例, B -3 が 5 例, B- 4 が 1 例, $\mathrm{C}$ が 5 例であった.

( 3 ) 歯の抵抗得点

平均 87.9 点（16〜126 点）であった.

\section{2. 下顎運動所見（表 4)}

(1) 最大開口量 (以下, 開口量と略す)

平均 $43.2 \mathrm{~mm}(28 \sim 58 \mathrm{~mm})$ であった.

(2) 側方限界運動量

側方限界運動量の平均は, 左 $8.1 \mathrm{~mm}(0 \sim 10 \mathrm{~mm})$, 右 $8.1 \mathrm{~mm}(2 \sim 12 \mathrm{~mm})$ であった.

開口量と側方限界運動量に相関はなかったが, 顎関 節損傷を有しないものに比べ, 有したものでは開口量 $(\mathrm{p}<0.05)$ および側方限界運動量 $(\mathrm{p}<0.001)$ は小さ かった.

\section{3 ，咀嚼筋筋電図所見（表 5)}

(1) タッピング可能回数

タッピング頻度を毎秒 1 回に規定したときの実際の 10 秒間のタッピング可能回数は平均 10.0 回, 毎秒 2 回では平均 20.0 回であったが, 毎秒 3 回では平均 29.1 回で規定タッピング回数より少なかった. Eichner 分 類 $\mathrm{B}-4$ および $\mathrm{C}$ の症例は, 兒歯部に咬合支持がある $\mathrm{A}, \mathrm{B}-1, \mathrm{~B}-2$ および $\mathrm{B}-3$ の症例に比べ, 毎秒 3 回のタッピング可能回数は少なかった $(\mathrm{p}<0.01)$.

(2) $\mathrm{sp}$ 出現率

\section{a）タッピング頻度規定時}

タッピング運動時の $\mathrm{sp}$ 出現率は, 毎秒 1 回では $57.4 \%$, 毎秒 2 回では $51.9 \%$, 毎秒 3 回では $48.2 \%$ で あり, 毎秒 1 回に比べ, 毎秒 3 回での $\mathrm{sp}$ 出現率は低かっ た $(\mathrm{p}<0.05)$. Eichner 分類 $\mathrm{B}-4$ および C の症例の
表 5 労災患者の咀嚼筋筋電図の所見

\begin{tabular}{c|c}
\hline 規定タッピング頻度 & 実際の 10 秒間タッピング回数 \\
\hline 1 回 $/$ 秒 & 10.0 回 \\
\hline 2 回 $/$ 秒 & 20.0 回 \\
\hline 3 回 $/$ 秒 & 29.1 回 \\
\hline & 平均 SP 出現率 (最低值 最高値 $)$ \\
\hline 1 回 $/$ 秒 & $57.4 \%(2.5 \sim 100 \%)$ \\
\hline 2 回 $/$ 秒 & $51.9 \%(\quad 0 \sim 100 \%)$ \\
\hline 3 回/秒 & $48.2 \%(\quad 0 \sim 100 \%)$ \\
\hline 頻度非規定時 & $59.0 \%(\quad 0 \sim 100 \%)$ \\
\hline
\end{tabular}

毎秒 1,2 および 3 回のタッピング運動時の $\mathrm{sp}$ 出現 率は, A, B-1, B-2 および B-3の症例に比べ低 かった $(\mathrm{p}<0.05)$. すなわち臼歯部の咬合関係を跋失 したものでは sp 出現率が低く, タッピング頻度の増 大とともに sp 出現率は低下した。 しかし一か所以上 臼歯部に咬合支持のあるものの間では sp 出現率に差 を認めなかった. 欠損歯数で対象症例を 2 群に分ける と, タッピング頻度別では毎秒 1 回の時には 18 歯以 上と未満の間で差を認め $(\mathrm{p}<0.05)$, 毎秒 2 回および 3 回では 15 歯以上と未満の間に差を認めた $(\mathrm{p}<0.05)$. 有床義歯装着者は非装着者に比べ $\mathrm{sp}$ 出現率は低かっ た $(\mathrm{p}<0.01)$.

b) タッピング頻度非規定時

患者が最も行いやすい任意のタッピング運動時の $\mathrm{sp}$ 出現率の平均は, $59.0 \%(0 \sim 100 \%)$ であった.こ の場合も Eichner 分類 B-4および C の症例では, A, $\mathrm{B}-1, \mathrm{~B}-2$ および $\mathrm{B}-3$ の症例に比べ $\mathrm{sp}$ 出現率は 低かった $(\mathrm{p}<0.05)$.

\section{4. デンタルプレスケールによる咬合所見}

51 例中 46 例は $30 \mathrm{H}$ で，その 46 例中 25 例は $50 \mathrm{H}$ で も咬合所見を調査した。

\section{(1) $30 \mathrm{H}$ での咬合所見 (図 1 )}

a) 労災患者

接触面積の平均は $25.8 \mathrm{~mm}^{2}\left(1.7 \sim 118.0 \mathrm{~mm}^{2}\right)$, 平 均咬合力の平均は $9.6 \mathrm{MPa}(7.3 \sim 11.7 \mathrm{MPa})$, 総咬合 力の平均は $231.4 \mathrm{~N}(19.0 \sim 832.0 \mathrm{~N})$, 有効率の平均は 84.9\% (55.8〜98.6\%) であった。

接触面積の左右差の平均は $28.0 \%$ (4.6 88.6\%), 総咬合力の左右差の平均は $24.0 \%(4.7 \sim 86.9 \%)$ であっ た.

\section{b) 健常者}

接触面積の平均は $54.1 \mathrm{~mm}^{2}\left(17.9 \sim 122.6 \mathrm{~mm}^{2}\right)$, 平 均咬合力の平均は $8.1 \mathrm{MPa}(6.8 \sim 9.4 \mathrm{MPa})$, 総咬合力 の平均は $411.4 \mathrm{~N}(168.2 \sim 783.7 \mathrm{~N})$, 有効率の平均は 88.9\% (82.6〜95.4\%) であった. 


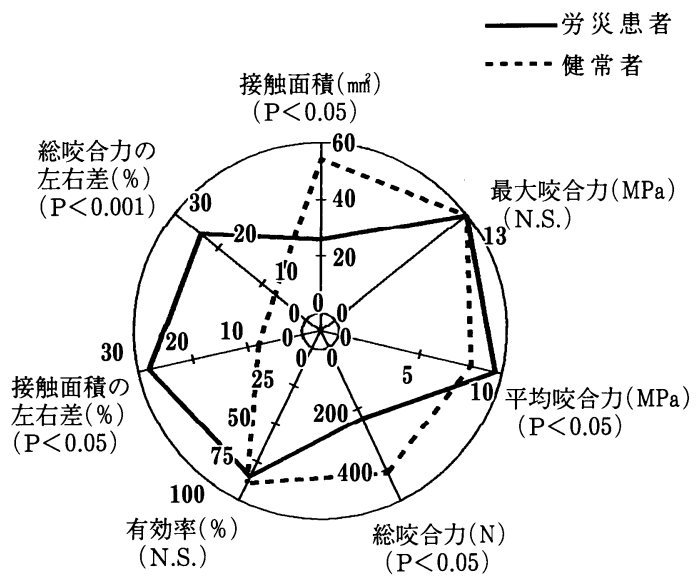

図 1 労災患者および健常者の $30 \mathrm{H}$ による咬合所見とそ の比較

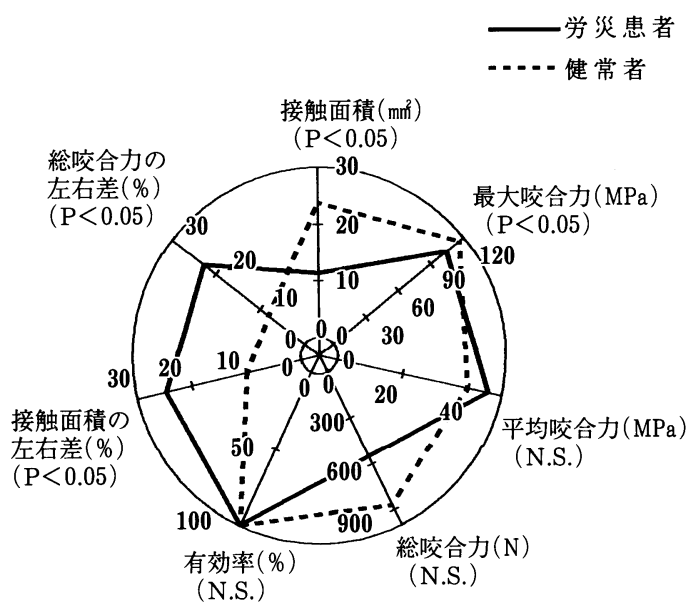

図 2 労災患者および健常者の $50 \mathrm{H}$ による咬合所見とそ の比較

接触面積の左右差の平均は $8.0 \%(0.2 \sim 15.8 \%)$, 総 咬合力の左右差の平均は $7.1 \%(0 \sim 13.8 \%)$ であった.

c）労災患者と健常者の比較

有効率は差を認めなかったが, 接触面積, 平均咬合 力, 総咬合力は健常者で大きく $(\mathrm{p}<0.05)$, 接触面積 の左右差, 総咬合力の左右差は, 健常者で小さかった ( $\mathrm{p}<0.05)$. なお, 健常者の男女間に差を認めなかった. 最大咬合力は労災患者, 健常者ともに, 全例が $30 \mathrm{H}$ の 測定限界の $13.0 \mathrm{MPa}$ であった。

(2) $50 \mathrm{H}$ での咬合所見（図 2 )

a) 労災患者

接触面積の平均は $11.3 \mathrm{~mm}^{2}\left(1.4 \sim 37.9 \mathrm{~mm}^{2}\right)$, 最
表 6 労災患者のテクチャー別の食品 の咀嚼可能率

\begin{tabular}{c|c}
\hline $\begin{array}{c}\text { 食品のテクス } \\
\text { チャーランク }\end{array}$ & $\begin{array}{c}\text { 咀嚼可能な被験 } \\
\text { 者の割合 }(\%)\end{array}$ \\
\hline 1 & 84.8 \\
\hline 2 & 81.0 \\
\hline 3 & 76.3 \\
\hline 4 & 68.0 \\
\hline 5 & 71.4 \\
\hline 6 & 58.6 \\
\hline 7 & 61.4 \\
\hline 8 & 59.0 \\
\hline 9 & 42.8 \\
\hline 10 & 47.7 \\
\hline \multicolumn{2}{|c|}{} \\
\hline 9
\end{tabular}

大咬合力の平均は $104.1 \mathrm{MPa}(56.9 \sim 120.0 \mathrm{MPa})$, 平 均咬合力の平均は $45.9 \mathrm{MPa}(31.4 \sim 58.9 \mathrm{MPa})$, 総咬 合力の平均は $552.8 \mathrm{~N}(45.5 \sim 1626.4 \mathrm{~N})$, 有効率の平均 は $99.5 \%$ (96.0〜100\%) であった.

接触面積の左右差の平均は $24.7 \%(1.5 \sim 82.3 \%)$, 総咬合力の左右差の平均は $22.8 \%(0.5 \sim 81.6 \%)$ であっ た.

\section{b) 健常者}

接触面積の平均は $23.8 \mathrm{~mm}^{2}\left(9.6 \sim 52.2 \mathrm{~mm}^{2}\right)$, 最 大咬合力の平均は $115.9 \mathrm{MPa}(100 \sim 120 \mathrm{MPa})$, 平均咬 合力の平均は $39.6 \mathrm{MPa}(27.0 \sim 50.9 \mathrm{MPa})$, 総咬合力 の平均は $872.5 \mathrm{~N}(396.7 \sim 1408.7 \mathrm{~N})$, 有効率の平均は 99.5\%（98.4〜100\%) であった.

接触面積の左右差の平均は $9.9 \%(0 \sim 20.8 \%)$, 総 咬合力の左右差の平均は $8.1 \%(0.6 \sim 18.2 \%)$ であっ た。

c）労災患者と健常者の比較

平均咬合力, 有効率, 総咬合力に差は認めなかった が, 接触面積, 最大咬合力は健常者で大きく（p< 0.05), 接触面積の左右差, 総咬合力の左右差は, 健常 者で小さかった $(\mathrm{p}<0.05)$. なお，健常者の男女間で は, 平均咬合力は男に比べ女で大きかった $(\mathrm{p}<0.05)$ が, 他項目で差は認めなかった.

\section{5 . 咀嚼可能食品問診調査}

労災患者全例の咀嚼可能率の平均は $67.4 \%$ （2.3 $100 \%$ ）であった。咀嚼可能率の分布は, 51 例中可能率 I が 23 例，II であった. 最も軟らかいテクスチャーランク 1 の食品 について, 咀嚼可能と答えたものは, 全症例の $84.8 \%$, 

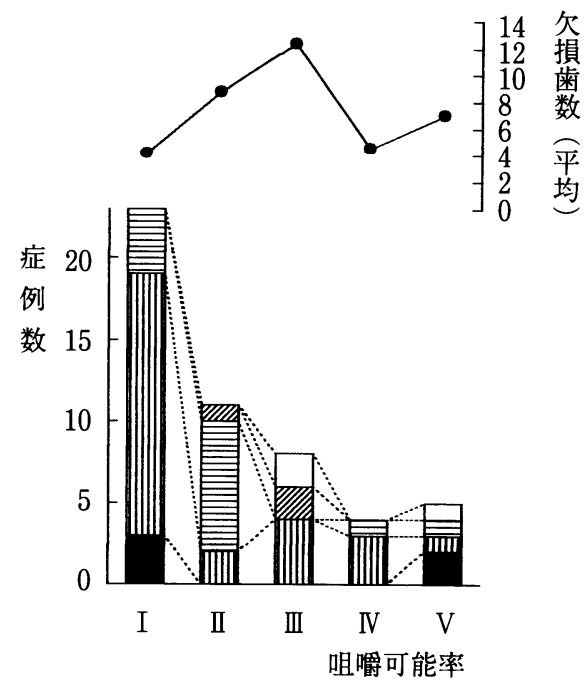

欠損歯数 0

||l|| 欠損歯数 1-6

三 欠損歯数 7-12

"IIII, 欠損歯数 13-18

$\square$ 欠損歯数 19-24

図 3 咀嚼可能率と欠損歯数
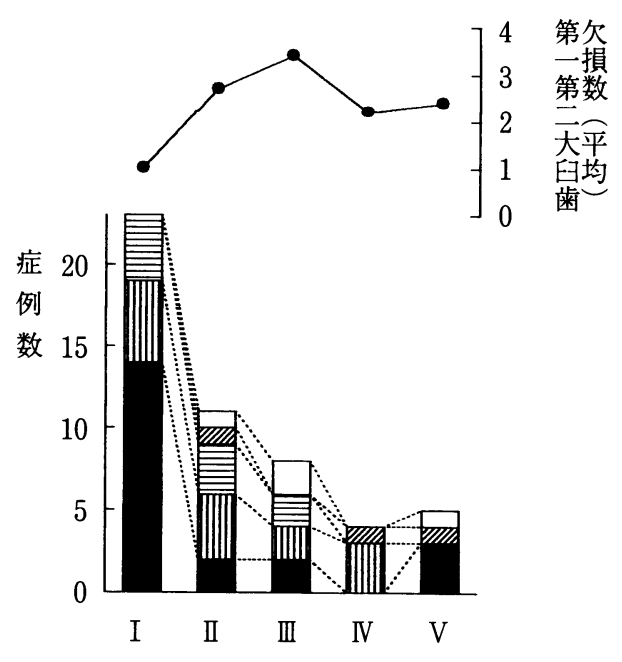

咀嚼可能率

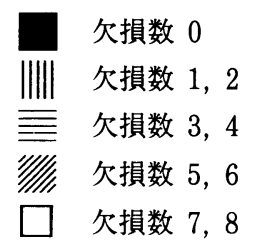

図 4 咀嚼可能率と第一, 第二大臼歯欠損数

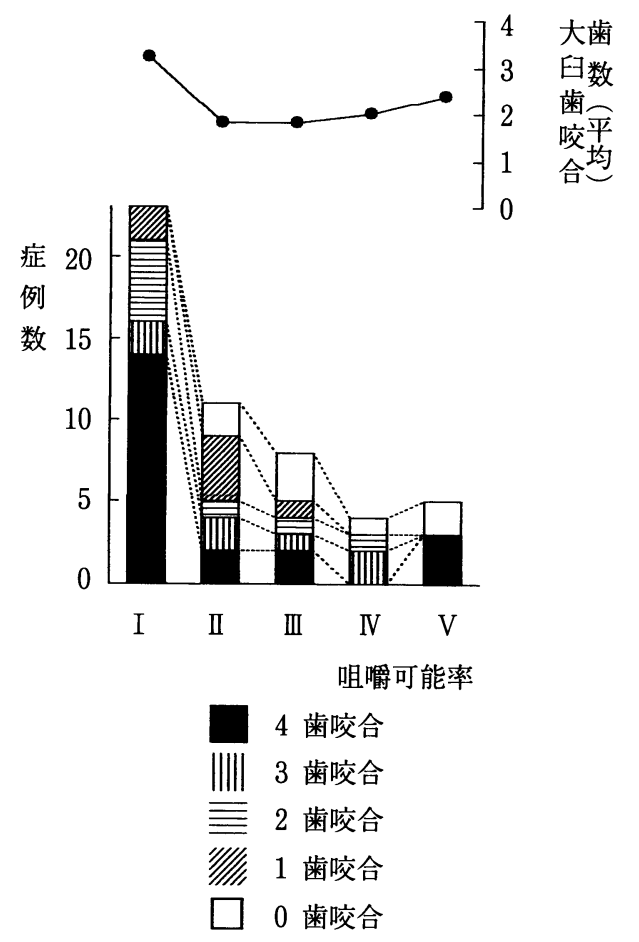

図 5 咀嚼可能率と大臼歯咬合歯数

最も硬いテクスチャーランク 10 の食品で $47.7 \%$ であっ た(表 6 ).

\section{6 . 各検查項目と咀嗳可能率の関係}

(1) 咀嚼可能率と歯の所見

欠損歯数の平均は可能率 I では 4.1 本，II では 8.7 本, IIIでは 12.3 本, IVでは 4.5 本, Vでは 7.0 本であっ た（図 3 ).

第一, 第二大曰歯の欠損数の平均は, 可能率 I では 1.0 本, II では 2.7 本, II では 3.4 本, IVでは 2.2 本, $\mathrm{V}$ では 2.4 本であった（図 4 ）。

第一, 第二大臼歯の咬合歯数の平均は, 可能率 I で は 3.2 歯, IIでは 1.8 歯, IIIでは 1.8 歯, IV では 2.0 歯, Vでは 2.4 歯であった（図 5 ).

Eichner 分類は, 可能率 I では全例 $\mathrm{A}$ および $\mathrm{B}-1$, IIでは $\mathrm{A}, \mathrm{B}-1$ および $\mathrm{B}-2$ が計 8 例, $\mathrm{B}-3$ および $\mathrm{B}-4$ が計 3 例，III では $\mathrm{A}$ が 3 例， B-3 および $\mathrm{C}$ が 計 5 例, $\mathrm{N}$ では $\mathrm{A}$ および $\mathrm{B}-1$ が計 3 例, $\mathrm{B}-3$ が 1 例, $\mathrm{V}$ では $\mathrm{A}$ が 3 例, $\mathrm{B}-3$ および $\mathrm{C}$ が各 1 例であっ た(図6).

歯の抵抗得点の平均は, 可能率 I では 99.2 点, II で は 79.2 点, IIIでは 70.5 点, IVでは 92.8 点, Vでは 79.4 点であった（図 7 ).

可能率 I から Vの歯の所見を比較すると, 各項目の 障害は可能率 I に比べII および吕で大きかった（p< 


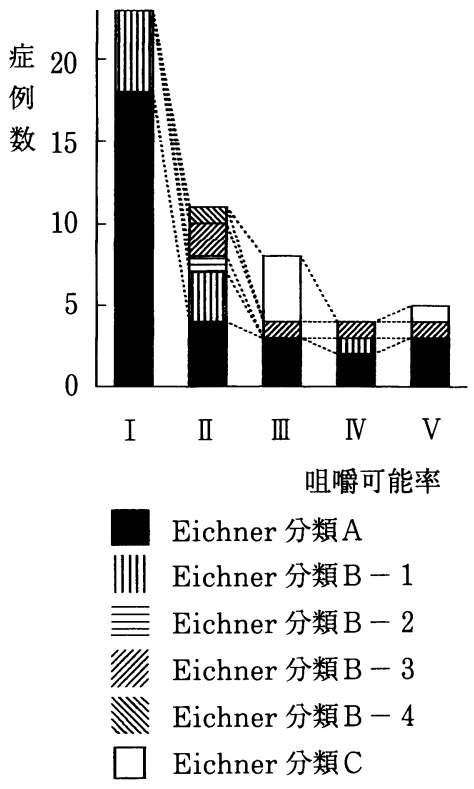

図 6 咀嚼可能率と Eichner 分類

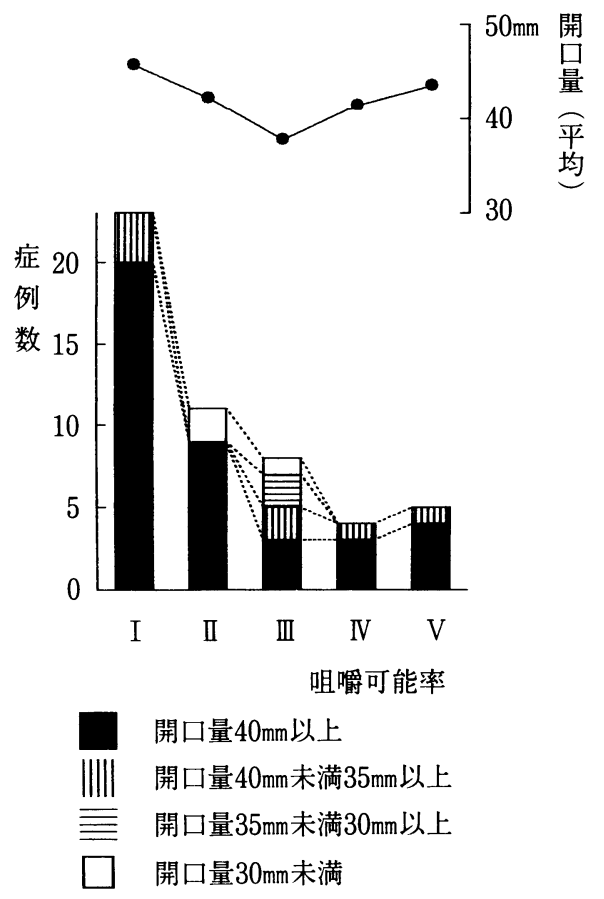

図 8 咀嚼可能率と開口量

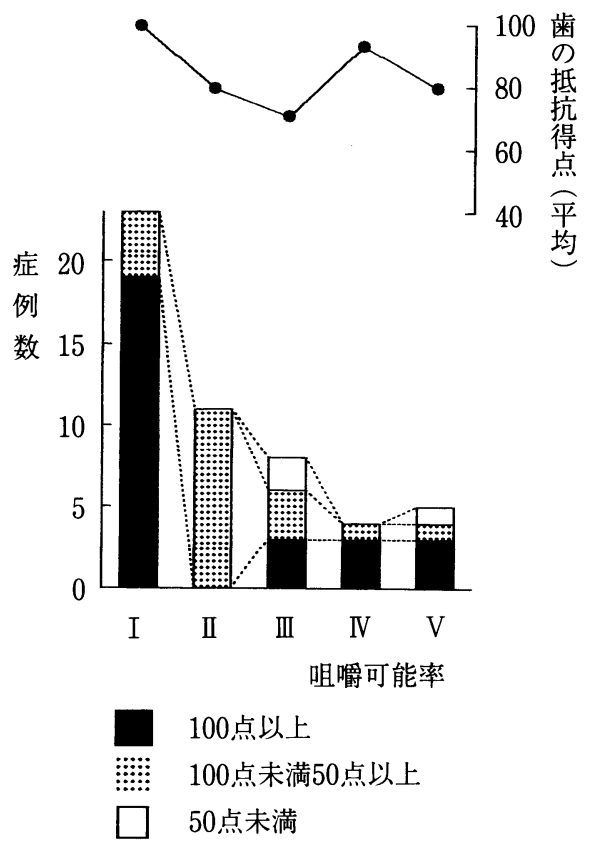

図 7 咀嚼可能率と歯の抵抗得点

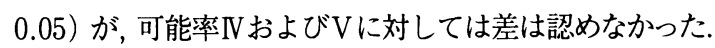
咀嚼可能率の各群での併発症の頻度をみると可能率 I では, 23 例中顎骨骨折 12 例, 額関節損傷 11 例であっ た. 可能率 II では, 11 例中顎骨骨折 5 例, 顎関節損傷 2 例であった. 可能率四では, 8 例中顎骨骨折 5 例, 顎関 節損傷 5 例であった. 可能率 V では，4 例中顎骨骨折 3 例, 顎関節損傷 2 例であった. 可能率 Vでは， 5 例中顎 骨骨折 2 例, 顎関節損傷 2 例であった.

(2) 咀嚼可能率と下顎運動量

開口量が $40 \mathrm{~mm}$ 未満の症例は 51 例中 12 例あり，こ の 12 例中 8 例は顎骨骨折例で, かつ顎関節損傷を認 めた。開口量が $40 \mathrm{~mm}$ 未満 $35 \mathrm{~mm}$ 以上の症例は 7 例 で, うち 3 例は顎骨骨折症例であった。この 3 例の咀 嚼可能率の平均は $61.0 \% \pm 28.9$, 残り 4 例は非骨折症 例で咀嚼可能率の平均は $58.1 \% \pm 45.4$ (90\%以上 2 例, $40.0 \%$ およ゙ $2.3 \%$ 各 1 例）とばらつきが大きかった. 開口量が $35 \mathrm{~mm}$ 未満の症例は 5 例あり, 全例が顎骨骨 折例で, その咀嚼可能率の平均は $56.8 \% \pm 12.4$ であっ た(図 8 ).

開口量の平均は, 可能率 I では $45.8 \mathrm{~mm}$, II では

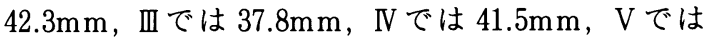
$43.6 \mathrm{~mm}$ であった (図 8 ). 可能率 I から III 範囲では 咀嚼可能率の低下とともに開口量は漸減した。可能率 I から Vの各群の開口量を比較すると, 可能率 I に比 べIおよび且の開口量が小さかった $(\mathrm{p}<0.05)$ が, 可 


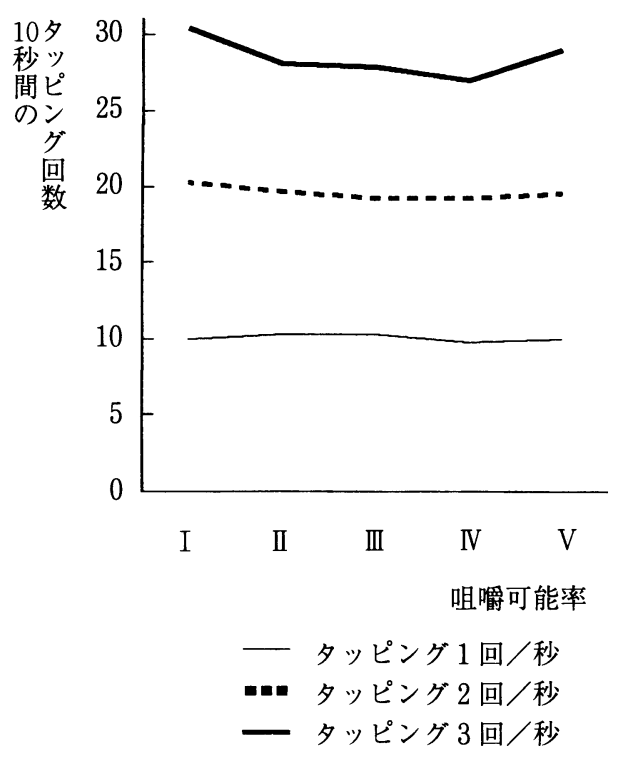

図 9 咀嚼可能率とタッピング回数

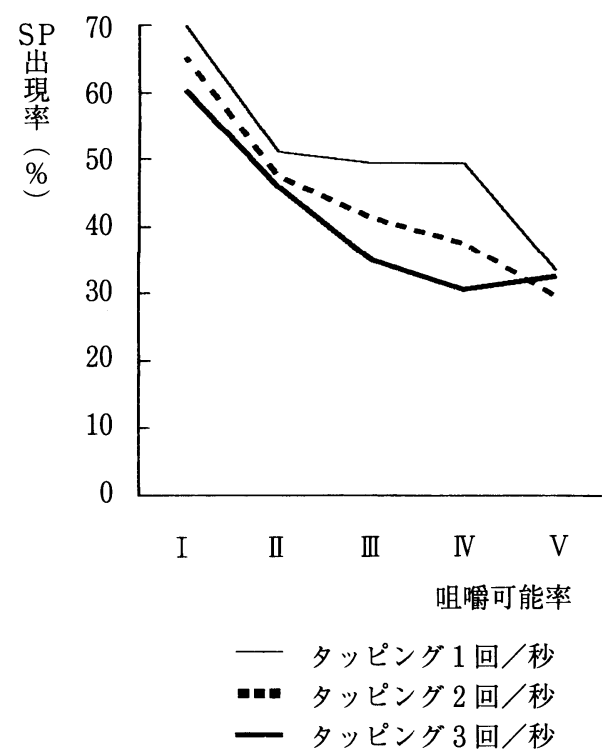

図 10 咀嚼可能率と SP 出現率
能率 IVおよびVとの間に差は認めなかった．可能率 IV およびVでは開口量 $40 \mathrm{~mm}$ 以上が 9 例中 7 例を占め, 他覚所見と問診回答の間に差を認めた。

側方運動では, 両側の可動域がともに $7 \mathrm{~mm}$ 未満の 症例は 7 例で, 全例が顎骨骨折例であった。このうち 咀嚼可能率 $40 \%$ 末満であったものは 1 例 (16.4\%) で, 開口量は $40 \mathrm{~mm}$ であった。

(3) 咀嚼可能率と咀嚼筋筋電図所見

タッピングは, 毎秒 1 回の速さでは全例ほほ規定の 頻度で行えた. 毎秒 2 回規定時の実際の 10 秒間の夕ッ ピング回数を比較すると, 可能率 I では 20.4 回，II で は 19.3 回，IIIでは 19.3 回, IVでは 19.0 回, Vでは 19.6 回であった. 毎秒 3 回規定時の実際の 10 秒間の夕ッ ピング回数を比較すると, 可能率 I では 30.4 回，II で は 28.1 回, IIIでは 27.9 回, IVでは 27.0 回, Vでは 29.0 回であった。 なお, 各咀嚼可能率の間に有意差は認め なかった（図 9 ).

毎秒 3 回のタッピング時の sp 出現率は, 可能率 I では $60.3 \%$, II では $45.9 \%$, III では $35.0 \%$, IV では $30.6 \%, V て ゙ は 32.5 \%$ であった。毎秒 1 回および 2 回 タッピング時の sp 出現率も毎秒 3 回と同様の傾向を 示した. 可能率 I から V の各群の $\mathrm{sp}$ 出現率を比較す ると, 可能率 I に比べII から V の全群で sp 出現率が 低かった $(\mathrm{p}<0.05)$ (図 10).

(4) 咀嚼可能率とデンタルプレスケールによる咬 合所見（表 7 )

a) $30 \mathrm{H}$ による咬合所見

接触面積の平均は, 可能率 I では $34.0 \mathrm{~mm}^{2}$, II では
$21.4 \mathrm{~mm}^{2}$, III では $19.4 \mathrm{~mm}^{2}, \mathrm{IV}$ では $13.2 \mathrm{~mm}^{2}, \mathrm{~V} て ゙$ は $12.2 \mathrm{~mm}^{2}$ であった. 総咬合力の平均は, 可能率 I で は $300.8 \mathrm{~N}$, II では $189.4 \mathrm{~N}$ ，III では $176.4 \mathrm{~N}$, IV では $124.1 \mathrm{~N}, \mathrm{~V}$ では $121.7 \mathrm{~N}$ であった. 接触面積の左右差の 平均は, 可能率 I では $17.8 \%$, II では $24.9 \%$, III では $39.1 \%, \mathrm{IV}$ では $47.8 \%, \mathrm{~V}$ では $61.0 \%$ でった. 総咬合 力の左右差の平均は, 可能率 I では $15.0 \%$, II では 23.4\%, III では $32.0 \%, \mathrm{~V}$ では $44.9 \%, \mathrm{~V}$ では $46.0 \%$ で あった. 可能率 I から V の咬合所見を比較すると，接 触面積および総咬合力は可能率 I に比べIVおよびVで 小さかった $(p<0.05)$. 接触面積および総咬合力の左 右差は可能率 I と II の間では差を認めなかったが，可 能率 IIIから Vでは I に比べ小さかった $(\mathrm{p}<0.01)$.

受傷部位が両側のものと片側のものに分けて左右差 をみると, 接触面積では両側 $26.3 \%$, 片側 $32.9 \%$, 総 咬合力では両側 $21.6 \%$, 片側 $31.7 \%$ で，ともに差は認 めなかった。

$30 \mathrm{H}$ による接触面積および総咬合力を, その平均值 以上と未満に分けて患者の咀嚼可能率と比較すると, 平均值以上の患者で高い值を示した $(p<0.05)$. 接触 面積の左右差, 総咬合力の左右差では, その値を平均 值以上と未満に分けて比較すると, 平均値以上のもの で咀嚼可能率が低かった $(p<0.001)$.

b) $50 \mathrm{H}$ による咬合所見

接触面積の平均は, 可能率 I では $14.1 \mathrm{~mm}^{2}$, II では $11.7 \mathrm{~mm}^{2}$, III では $6.2 \mathrm{~mm}^{2}, \mathrm{IV}$ では $4.5 \mathrm{~mm}^{2}$ であった. 最大咬合力の平均は, 可能率 I では $113.2 \mathrm{MPa}$, II で は $103.9 \mathrm{MPa}$, III では 81.5MPa , IV では 81.6MPa で 
表 7 労災患者の咀嚼可能率別のデンタルプレスケールによる咬合所見

\begin{tabular}{|c|c|c|c|c|c|c|c|c|c|c|}
\hline \multirow{2}{*}{\multicolumn{2}{|c|}{ 咀䍛可能率 }} & \multirow{2}{*}{$\begin{array}{l}\mathrm{I} \\
30 \mathrm{H}(\mathrm{n}=22) \\
50 \mathrm{H}(\mathrm{n}=12)\end{array}$} & \multirow{2}{*}{$\begin{array}{l}\text { II } \\
30 \mathrm{H}(\mathrm{n}=10) \\
50 \mathrm{H}(\mathrm{n}=7)\end{array}$} & \multirow{2}{*}{$\begin{array}{l}\text { III } \\
30 \mathrm{H}(\mathrm{n}=7) \\
50 \mathrm{H}(\mathrm{n}=3)\end{array}$} & \multirow{2}{*}{$\begin{array}{l}\text { IV } \\
30 \mathrm{H}(\mathrm{n}=4) \\
50 \mathrm{H}(\mathrm{n}=2)\end{array}$} & \multirow{2}{*}{$\begin{array}{l}\mathrm{V} \\
30 \mathrm{H}(\mathrm{n}=3) \\
50 \mathrm{H}(\mathrm{n}=1)\end{array}$} & \multicolumn{3}{|c|}{ 可能率 I との比較 } & \multirow{2}{*}{$\begin{array}{l}\text { 平均値以 } \\
\text { 上と末満 } \\
\text { の比較 }\end{array}$} \\
\hline & & & & & & & II & III & $\mathrm{IV}, \mathrm{V}$ & \\
\hline \multirow{6}{*}{$\begin{array}{l}30 \\
\mathrm{H}\end{array}$} & $\begin{array}{l}\text { 接触面積 } \\
\text { 最低 最高 }\end{array}$ & $\begin{array}{l}34.0 \mathrm{~mm}^{2} \\
7.4 \sim 118.0\end{array}$ & $\begin{array}{l}21.4 \mathrm{~mm}^{2} \\
8.8 \sim 63.6\end{array}$ & $\begin{array}{l}19.4 \mathrm{~mm}^{2} \\
1.7 \sim 46.1\end{array}$ & $\begin{array}{l}13.2 \mathrm{~mm}^{2} \\
7.0 \sim 18.6\end{array}$ & $\begin{array}{l}12.2 \mathrm{~mm}^{2} \\
2.4 \sim 20.1\end{array}$ & N.S. & N.S. & $*$ & $*$ \\
\hline & $\begin{array}{l}\text { 平均咬合力 } \\
\text { 最低 } \\
\text { 最高 }\end{array}$ & $\begin{array}{l}9.5 \mathrm{MPa} \\
6.4 \sim 11.5\end{array}$ & $\begin{array}{l}9.5 \mathrm{MPa} \\
7.9 \sim 11.3\end{array}$ & $\begin{array}{l}10.0 \mathrm{MPa} \\
9.0 \sim 11.7\end{array}$ & $\begin{array}{l}9.6 \mathrm{MPa} \\
7.3 \sim 10.9\end{array}$ & $\begin{array}{l}10.6 \mathrm{MPa} \\
10.4 \sim 10.8\end{array}$ & N.S. & N.S. & N.S. & N.S. \\
\hline & $\begin{array}{l}\text { 総咬合力 } \\
\text { 最低～最高 }\end{array}$ & $\begin{array}{l}300.8 \mathrm{~N} \\
68.9 \sim 832.0\end{array}$ & $\begin{array}{l}189.4 \mathrm{~N} \\
48.8 \sim 516.3\end{array}$ & $\begin{array}{l}176.4 \mathrm{~N} \\
19.5 \sim 415.1\end{array}$ & $\begin{array}{l}124.1 \mathrm{~N} \\
68.0 \sim 191.7\end{array}$ & $\begin{array}{l}121.7 \mathrm{~N} \\
0.0 \sim 208.8\end{array}$ & N.S. & N.S. & $*$ & * \\
\hline & 有効率 & $85.8 \%$ & $87.4 \%$ & $83.0 \%$ & $84.8 \%$ & $80.8 \%$ & N.S. & N.S. & N.S. & N.S. \\
\hline & $\begin{array}{l}\text { 面皘左右差 } \\
\text { 最低～最高 }\end{array}$ & $\begin{array}{l}17.8 \% \\
5.0 \sim 36.1\end{array}$ & $\begin{array}{l}24.9 \% \\
4.6 \sim 88.6\end{array}$ & $\begin{array}{l}39.1 \% \\
27.5 \sim 49.7\end{array}$ & $\begin{array}{l}47.8 \% \\
36.6 \sim 71.0\end{array}$ & $\begin{array}{l}61.0 \% \\
35.9 \sim 83.1\end{array}$ & N.S. & $* *$ & $* *$ & $* * *$ \\
\hline & $\begin{array}{r}\text { 咬合力左右差 } \\
\text { 最低 最高 }\end{array}$ & $\begin{array}{l}15.0 \% \\
4.7 \sim 31.1\end{array}$ & $\begin{array}{l}23.4 \% \\
6.9 \sim 86.9\end{array}$ & $\begin{array}{l}32.0 \% \\
16.0 \sim 45.9\end{array}$ & $\begin{array}{l}44.9 \% \\
31.3 \sim 68.8\end{array}$ & $\begin{array}{l}46.0 \% \\
29.0 \sim 82.9\end{array}$ & N.S. & $* *$ & $* *$ & $* * *$ \\
\hline \multirow{7}{*}{$\begin{array}{c}50 \\
\mathrm{H}\end{array}$} & $\begin{array}{l}\text { 接触面積 } \\
\text { 最低 最高 }\end{array}$ & $\begin{array}{l}14.1 \mathrm{~mm}^{2} \\
3.7 \sim 37.9\end{array}$ & $\begin{array}{l}11.7 \mathrm{~mm}^{2} \\
4.3 \sim 31.3\end{array}$ & $\begin{array}{l}6.2 \mathrm{~mm}^{2} \\
1.5 \sim 15.1\end{array}$ & $\begin{array}{l}4.5 \mathrm{~mm}^{2} \\
1.3 \sim 7.6\end{array}$ & $\begin{array}{c}3.2 \mathrm{~mm}^{2} \\
-\end{array}$ & N.S. & N.S. & $*$ & N.S. \\
\hline & $\begin{array}{l}\text { 最大咬合力 } \\
\text { 最低 最高 }\end{array}$ & $\begin{array}{l}113.2 \mathrm{MPa} \\
101.5 \sim 120\end{array}$ & $\begin{array}{l}103.9 \mathrm{MPa} \\
97.0 \sim 107.5\end{array}$ & $\begin{array}{l}81.5 \mathrm{MPa} \\
56.9 \sim 97.2\end{array}$ & $\begin{array}{l}81.6 \mathrm{MPa} \\
60.0 \sim 103.1\end{array}$ & $\begin{array}{c}110.3 \mathrm{MPa} \\
-\end{array}$ & $*$ & $* *$ & * & $*$ \\
\hline & $\begin{array}{l}\text { 平均咬合力 } \\
\text { 最低 最高 }\end{array}$ & $\begin{array}{l}48.0 \mathrm{MPa} \\
33.9 \sim 60.3\end{array}$ & $\begin{array}{l}47.1 \mathrm{MPa} \\
42.6 \sim 53.9\end{array}$ & $\begin{array}{l}39.6 \mathrm{MPa} \\
31.5 \sim 48.3\end{array}$ & $\begin{array}{l}37.5 \mathrm{MPa} \\
36.3 \sim 38.6\end{array}$ & $\underset{-}{49.5 \mathrm{MPa}}$ & N.S. & N.S. & N.S. & N.S. \\
\hline & $\begin{array}{l}\text { 総咬合力 } \\
\text { 最低～最高 }\end{array}$ & $\begin{array}{l}737.1 \mathrm{~N} \\
196 \sim 1282.8\end{array}$ & $\begin{array}{l}534.4 \mathrm{~N} \\
231.2 \sim 1276.3\end{array}$ & $\begin{array}{l}241.9 \mathrm{~N} \\
64.3 \sim 590.9\end{array}$ & $\begin{array}{l}169.4 \mathrm{~N} \\
44.4 \sim 294.3\end{array}$ & $\begin{array}{c}160.0 \mathrm{~N} \\
-\end{array}$ & N.S. & $*$ & $*$ & $*$ \\
\hline & 有効率 & $99.2 \%$ & $100 \%$ & $100 \%$ & $99.9 \%$ & $98.3 \%$ & N.S. & N.S. & N.S. & N.S. \\
\hline & $\begin{array}{l}\text { 面皘左右差 } \\
\text { 最低 最高 }\end{array}$ & $\begin{array}{l}19.8 \% \\
1.5 \sim 63.7\end{array}$ & $\begin{array}{l}24.1 \% \\
2.6 \sim 82.3\end{array}$ & $\begin{array}{l}41.1 \% \\
16.2 \sim 61.5\end{array}$ & $\begin{array}{l}41.9 \% \\
12.4 \sim 71.3\end{array}$ & $\begin{array}{c}3.1 \% \\
-\end{array}$ & N.S. & N.S. & N.S. & N.S. \\
\hline & $\begin{array}{r}\text { 咬合力左右差 } \\
\text { 最低 最高 }\end{array}$ & $\begin{array}{l}17.7 \% \\
0.5 \sim 47.1\end{array}$ & $\begin{array}{l}23.2 \% \\
2.7 \sim 81.6\end{array}$ & $\begin{array}{l}39.6 \% \\
7.7 \sim 64.4\end{array}$ & $\begin{array}{l}42.7 \% \\
20.9 \sim 64.4\end{array}$ & $\begin{array}{c}11.7 \% \\
-\end{array}$ & N.S. & $*$ & N.S. & N.S. \\
\hline
\end{tabular}

あった. 総咬合力の平均は, 可能率 I では $737.1 \mathrm{~N}$, II では $534.4 \mathrm{~N}$, III では $241.9 \mathrm{~N}, \mathrm{IV} て ゙ は ~ 169.4 \mathrm{~N}$ であった. 接触面積の左右差の平均は, 可能率 I では $19.8 \%$, II では $24.1 \%$, II では $41.1 \%$, IVでは $41.9 \%$ であった。 総咬合力の左右差の平均は, 可能率 I では $17.7 \%$, II では $23.2 \%$, IIIでは $39.6 \%$, IVでは $42.7 \%$ でった。 なお, 可能率 $\mathrm{V}$ の症例は 1 例のみであった。最大咬合 力は可能率 Iに比べIIか IVすべてにおいて小さかっ た $(\mathrm{p}<0.05)$. 総咬合力は可能率 I に比べ吕および $\mathrm{I}$ で小さかった $(\mathrm{p}<0.05)$. 総咬合力の左右差では可能 率 I と II の間に差は認めなかったが, 可能率 IIIでは大 きかった $(\mathrm{p}<0.05)$.

受傷部位が両側のものと片側のものに分けて左右差 をみると, 接触面積は両側 $23.4 \%$, 片側 29.7\%, 総咬 合力は両側 $22.4 \%$, 片側 $28.7 \%$ ，ともに差を認めな かった。
$50 \mathrm{H}$ による最大咬合力および総咬合力の值を平均值 以上と未満で分け, 患者の咀嚼可能率を比較すると咀 嚼可能率は平均值以上の患者で大きかった $(\mathrm{p}<0.05)$. 接触面積の左右差, 総咬合力の左右差で，その值を平 均值以上と未満に分けて患者の咀嚼可能率を比較する と差を認めなかった。

なお, 労災患者の咀嚼可能率別のデンタルプレスケー ルによる咬合所見を健常者と比較すると, 労災患者で は咀翾可能率の低下とともに差が認められる項目が多 くなった (表 8 ).

(5) 咀嚼可能率と各調査項目との関係

デンタルプレスケール $50 \mathrm{H}$ で測定し全資料が整っ ていた 25 例について多変量解析を行ったところ, 重 相関係数は 0.832 , 自由度調節済寄与率は 0.630 で, 下 記の咀嚼可能率を推定する式が得られた.

$\mathrm{Y}=11.406-1.582 \mathrm{X}_{1}+4.724 \mathrm{X}_{2}-0.443 \mathrm{X}_{3}+0.962 \mathrm{X}_{4}$ 
表 8 デンタルプレスケールによる咬合所見の咀嚼可能率別の労災患 者と健常者の計測結果の比較

\begin{tabular}{|c|c|c|c|c|c|c|c|c|}
\hline \multirow[t]{2}{*}{ 咀嚼可能率 } & \multicolumn{2}{|c|}{ I } & \multicolumn{2}{|c|}{ II } & \multicolumn{2}{|c|}{ III } & \multicolumn{2}{|c|}{$\mathrm{IV}, \mathrm{V}$} \\
\hline & $30 \mathrm{H}$ & $50 \mathrm{H}$ & $30 \mathrm{H}$ & $50 \mathrm{H}$ & $30 \mathrm{H}$ & $50 \mathrm{H}$ & $30 \mathrm{H}$ & $50 \mathrm{H}$ \\
\hline 接触面積 & N.S. & N.S. & $*$ & N.S. & $*$ & $*$ & $* *$ & $*$ \\
\hline 最大咬合力 & - & N.S. & - & $* *$ & - & $* *$ & - & $*$ \\
\hline 平均咬合力 & $*$ & N.S. & $*$ & N.S. & $*$ & N.S. & $*$ & N.S. \\
\hline 総咬合力 & N.S. & N.S. & $*$ & N.S. & & $*$ & $* *$ & $*$ \\
\hline 有効率 & N.S. & N.S. & N.S. & N.S. & N.S. & N.S. & N.S. & N.S. \\
\hline 接触面積の差 & $* *$ & N.S. & $*$ & N.S. & $* *$ & $*$ & $* *$ & $*$ \\
\hline 総咬合力の差 & $* *$ & N.S. & $*$ & N.S. & $* *$ & $*$ & $* *$ & $*$ \\
\hline
\end{tabular}

能に障害を残すもの」と判断した場合には 咀嚼障害の程度に差があっても一律の評 価となっている。

船越は, 咀嚼を動物の捸食行動の一部で, 食物を咬断, 粉砕, 臼磨して唾液と混和し, 食塊を形成して燕下するまでの動作であ り, 脳, 神経, 咀嚼筋, 歯, 舌などの口腔諸 器官の協調によって行われると定義し, 咀 嚼障害を (1) 咀嚼機能発達不全, (2) 咀 嚼システムの器質的疾患, (3) 咀嚼シス テムの機能的疾患, (4) 心因性咀嚼障害, に分類している ${ }^{6)}$.

労災患者の咀嚼障害の認定では，このう ちの (2)の咀嚼システムの器質的疾患お よび (3) の咀嚼システムの機能的疾患,

$\mathrm{X}_{1}$ : 毎秒 3 回規定時の 10 秒間の実際のタッピング回数 $\mathrm{X}_{2}$ : 大臼歯咬合歯数

$\mathrm{X}_{3}: 30 \mathrm{H}$ による接触面積の左右差

$\mathrm{X}_{4}: 50 \mathrm{H}$ による最大咬合力

$\mathrm{X}_{3}$ および $\mathrm{X}_{4}$ を除いた重相関係数は 0.600 , 自由度 調節済寄与率は 0.302 であった。さらに，30Hによる 接触面積の左右差, $50 \mathrm{H}$ による最大咬合力, 総咬合力, 総咬合力の左右差の 4 項目から算出した重相関係数は 0.787 , 自由度調節済寄与率は 0.544 であった。

\section{考察}

わが国において, 労働者の被った業務上の災害につ いて, 災害補償の制度が法制に現れたのは,「官役人夫 死傷手当規則」(明治 8 年太政官達第 54 号) や「各庁 技術工芸ノ者就業上死傷)節手当内規」(明治 12 年太 政官達第 4 号) である. その後, 昭和 2 年 4 月労発第 15 号通達 (工場法施工令第 7 条 - 鉱夫労役扶助規則第 20 条）により障害区分の標準を定めるにいたり，これが 今日の障害区分の原型とみられるものになった．昭和 22 年, 労働基準法が制定され, 同法 8 号に災害補償の 規定が設けられ，労働者災害保険法が制定された。こ のように補償制度が充実されてきた過程において障害 等級表は改正され,「口の障害」は, 昭和 50 年労働省 令第 23 号で,「10 歯以上に対して歯科補綴を加えたも の」および「5歯以上に対して歯科補経を加えたもの」 が増設され，咀嚼および言語機能障害を 6 段階, 歯の 障害を 5 段階に区別する障害等級が定められた ${ }^{1)}$. し かし, 等級認定基準は以後 20 年間曖昧なまま何も変 更されていない.

以上が現在までの「口の障害」の等級の改正の経緯 と概要であり,これが交通事故等の後遺障害の基準な どにも広く用いられている。しかし, 咀嚼障害はその 程度がさまざまであるにもかかわらず, 先にも述べた ように，その認定の判定基準は不明確で,「そしゃく機
について検討する必要があると思われた。これは労災 患者の障害は単に歯の亦失に止まらず, 顎骨や顎関節 の損傷等を併発することが多く, 器質的障害と機能的 障害が複雑に絡んでいる可能性があるからである。そ こで, 著者らは器質的障害として歯の所見, 機能的障 害として下顎運動所見, 咀嚼筋筋電困所見, 咬合所見 を分析し, 咀嚼可能率との関連を調査し, 咀嚼障害の 評価方法としての応用の可能性について検討した。さ らに, 労災に対する補償は, 障害の程度によって補償 が大きく異なることを患者が熟知しているという問題 が絡み, 器質的障害が小さいにもかかわらず咀嚼可能 率が著しく低い患者が存在し, 詐病が包含されている 可能性も考えられ，この点についても考慮を必要とする.

大塚は咀嚼能力に関する因子として（1）食品の物 性,（2）唾液の分泌量,（3）咬合状態，（4）歯周組織 の状態，（5）笳神経機構，（6）全身の状態, の 6 項 目 7) を指摘している.しかしながら，これらの因子に より咀嚼能力を評価する際, それぞれがどのような重 みをもって関与しているのかは解明されていない。ま た，各因子を正確に調査することは容易ではない。

咀嚼能力の評価方法としては, 試験食品を用いた直 接的な試験法として, 石原の篩分法 ${ }^{8}$ ), 増田らの ATP 顆粒剂を利用する方法 ${ }^{9}$ ), 加藤らの画像解析を応用し 咀嚼粉砕能力を観察する方法 ${ }^{10,11)}$ 等がある.

生理的な咀嚼をいとなむ場合には, 直接的な試験法 で咀嚼能力を評価することが可能であるが, 重大な咀 嚼障害が存在する場合, 咀嚼に関わる各因子が複雑に 絡み合い，1つの指標で表すことがしばしば困難であ る.そこで, 患者が咀嚼できる食品の問診により，間 接的に咀嚼能力を評価しようとする研究がいくつか行 われている.これらの評価方法としては, 山本の総義 歯性能判定表を用い捸取可能食品から判定する方 法 $^{12)}$, 松浦らの食品摂取状況, 食品のテクスチャー別 粉砕状況さらに患者の口腔内所見を組み合わせた方 法 $^{13)}$, 佐藤ら ${ }^{14)}$, 平井ら ${ }^{15)}$, 越野ら 16) の「咀嚼スコア 
一」, 内田 ${ }^{17)}$ の「摂取可能率」等が報告されている.

本研究では, 労災患者の咀嚼能力を数量化するため, テクスチャーが調査されている食品を問診調査し咀嚼 可能率を算出した. 本方法は, 特殊な機器を必要とせ ず，また食品テクスチャーは食品の咀嚼の難易度と関 係する15)ことから，咀嚼能力を推定するために簡便で 有効な方法であると考えた．ただし，内田は，間接的 な方法は評価が患者の主観に影響され，客観性に欠け る可能性がある ${ }^{17)}$ と述べており，本研究では，他覚所 見との対比を行うことによりこれを補うこととした．

佐藤らは, 咀嚼機能の評価を行うには, 食品の数は 多ければ多いほど正確な評価ができ, 食品の重み付け は，たまたま重みの大きい食品が食べられた場合，ス コアが高くなり正当な評価の妨げとなる可能性を否定 できず，スコアの算定も複雑になる ${ }^{14)}$ と指摘している. 本研究においても 173 食品を用い食品に重み付けを行 わずに咀嚼可能率を算出した。

本研究での咀嚼可能食品問診調查の結果では, テク スチャーランク 1 の最も軟らかい食品の摂取が可能で あったものは $84.8 \%$, 最も硬いランク 10 で $47.7 \%$ と， テクスチャーランクの増加とともに減少した。一方, 平井らの総義歯患者を対象とした調查（5段階評価） では, 最も軟らかい硬度 I の食品を $97.4 \%$ の被験者が 摂取でき, 最も硬い硬度 Vの食品で $32.6 \%$ が摂取でき た ${ }^{15)}$ としている. 本研究の対象症例は Eichner 分類 の $\mathrm{A}$ および $\mathrm{B}-1$ が多く，すべて有歯顎であったにも かかわらず, 軟らかい食品で平井らの総義歯患者に比 べ低い值であった.

今回の調査での, Eichner 分類と咀嚼可能率との関 係をみると可能率 I から IIIでは, 咀嚼可能率の低下と ともに咬合関係の保たれていない症例が増加した．し かしながら，可能率 $\mathrm{I}$ およびVの 9 例では， C が 1 例， $\mathrm{B}-3$ が 2 例, $\mathrm{A}$ および $\mathrm{B}-1$ が計 6 例で, 可能率 I と の間に大きな差は認められず, 自他覚所見が整合しな い症例が認められた。しかし，全体でみると B - 3 以 上と B-4 以下で区分した場合に差が認められた $(\mathrm{p}<0.05)$. 幸阪らは有床義歯での調査でピーナッツ粉 砕能力は咬合支持のないものが一番低く, 次に咬合支 持のある両側性義歯, 片側性義歯の順に高くなる18) と, 咬合支持域の数と咀嚼能率との関連性を指摘している. また, 鈴木らも咬合支持域数が多いほど咀嚼能力が高 くなる傾向を認めた19）と報告している.

次に欠損歯数と咀嚼可能率の関連をみると, 欠損歯 数は, 可能率 Iに比べI では約 2 倍，IIでは約 3 倍に 増大した. さらに, 欠損歯数 10 歯以下と 11 歯以上と の間に, 咀嚼可能率に差を認めた $(\mathrm{p}<0.05)$ 。これは 後藤らの補緅処置が完了していれば 10 歯前後以下の 欠損歯数であれば, 年齢を問わず大体の食品を噛むこ とができる ${ }^{20)}$ ，との報告にほほ一致していた。一方， 平野らは咀嚼能力 5 (ほとんどの食品が咀嚼可能）の
平均天然歯数は, 14.54 本つまり 欠損歯数約 13 本, 咀 嚼能力 3 (常食咀嚼可能) の平均天然歯数は 3.48 本つ まり欠損歯数約 24 本 $^{21)}$, と報告している. 本研究では 垴失歯数が少ないにもかかわらず咀嚼障害が出現して いるものがあり，これは労災患者では歯の欠損以外の 要因が咀嚼障害に関与している可能性を示唆するもの と考えられた。

歯の抵抗得点は, 残存歯の状態から咀嚼能力を評価 する目的で, ブリッジの支台歯の負担能力をもとに重 み付け3）を行い，歯種の違いを残存歯数に加味するた めに算出したものである. 第三大臼歯を含め 32 本の 歯がそろっている場合の抵抗得点の合計は 126 点であ るが, 全大臼歯 12 本が欠損すると得点は 62 点に半隇 し, 同じ 12 本でも前歯の欠損では 96 点となる. 対象 例を歯の抵抗得点の点数で 2 群に分けた場合 50 点以 上と 50 点未満で差が認められた $(\mathrm{p}<0.05)$.この低い 領域で有意差の発生は, 点数の大きい歯の欠損が咀嚼 障害と重要な関係をもつためと思われた.

最大開口量は, 歯の所見と同様に, 咀嚼可能率の低 下とともに減少した。咀嚼障害が出現する最大開口量 は約 $35 \mathrm{~mm}$ であったが，これはSzentpetery ${ }^{22)}$ の開 口障害を規定する開口量, 野首ら ${ }^{23)}$ の顎関節症での開 口障害を規定する開口量とも一致した。咀嚼可能率は 開口量 $35 \mathrm{~mm}$ 以上と末満を比べると, $35 \mathrm{~mm}$ 末満で 低く $(\mathrm{p}<0.01), 35 \mathrm{~mm}$ 未満では可能率 I のものは 1 例も認めなかった。

歯の所見および開口量から咀嚼可能率をみると, 可 能率 I から IIIの患者では, 咀嚼可能率の低下とともに 歯の障害は漸増し, 開口量は漸減した。一方, 可能率 IV およびVの患者では，歯の障害が小さく開口障害が 少ないにもかかわらず, 軟らかい食品が咀嚼できない と回答しており，歯の所見と開口量のみではその原因 を説明できないものが含まれていた.

藤井によると,タッピング運動には，（1）開口，閉 口，噛みしめなど下顎運動の基本的な動作要素が含ま れている，(2) 特殊な練習をしなくても誰にでもでき る単純な運動である，（３）ほほ一定のリズムをもつ運 動の反復が容易である，（4) 生体におよぼす種々の影 響がほとんどない，（５）上下顎歯列間に食品などが介 在せず解釈が困難な外乱因子が関与する機会が少ない, 等の特徴があり，下顎の運動学的な研究に広く利用さ れている.しかし，一見単純にみえるタッピング運動 も決して固定された運動でなく, 自由度のある条件付 けされやすい動作であると考えたほうがこの運動をよ く説明できる24) と述べている. 小松らは, タッピング 運動時のタッピング頻度は, 健常者では毎秒 3 回で筋 電波形が最も安定し，1，2 回では 3 回に比べ安定し ない25）と報告している. 山鹿らは, 総義歯装着者で可 能なタッピング頻度は, 毎秒 2 回である ${ }^{26)}$ と報告して いる.タッピング時の sp 出現率は健常者では新谷 
ら ${ }^{27)}$ や小 ${ }^{28)}$ は $90 \%$ 前後, 近藤は良好な総義歯装着 者では $72 \%$ であった ${ }^{29)}$ ，と報告している.すなわち健 常者に比べ総義歯装着者では咀嚼可能率は低いと考え られることから, 顎口腔機能の障害が大きくなると sp 出現率は低下し, タッピング可能回数が少なくなると 推測された. そこで, 本研究でも咀嚼可能率と下顎運 動時の咀嚼筋筋電図所見との関係を調べるため，タッ ピング頻度規定時の実際のタッピング可能回数および タッピング時の sp 出現率を測定した. その結果, タッ ピング頻度では, 毎秒 3 回のタッピングが行えないも のは 11 例で, その内訳は可能率 I が 1 例, II が 4 例, IIIからVが各 2 例であった. 可能率 I から IIIの 7 例は 全例顎骨骨折症例で平均年齢 55.8 歳, うち 4 例が義歯 装着例であった. 可能率 IVおよびVの 4 例は, 平均年 齢 41.0 歳, うち 1 例は顎骨骨折症例, 3 例は Eichner 分類 $\mathrm{A}$, 平均欠損歯数は 3.3 本であった. さらに毎秒 2 回のタッピングが行えないものは 6 例で, その内訳は 可能率 I が 1 例, II が 2 例，III から V が各 1 例であっ た. 可能率 I から IIIの 4 例はすべて顎骨骨折症例でか つ, 義歯装着例であり, 平均年齢 62.3 歳であった. 可 能率 $\mathrm{V}$ およびVの 2 例は平均年齢 39.0 歳, Eichner 分 類 A, 平均欠損歯数 2.0 本であった. 可能率 I から III ではタッピングが十分にできないものは高齢者に多く, 長澤らの高齢者ではタッピング頻度が低下する ${ }^{30 ）}$ と の報告に一致したが, 可能率 IVおよびVでは比較的若 年者が多く, 所見に矛盾があった。また，全部床義歯 患者で可能なタッピング速度は 120 回／分であり 26), 正常咬合を有する者では毎秒 3 回のタッピング運動で の筋電波形が最も安定している25）と言われている. 本 研究においても可能率 $40 \%$ 未満を除けば歯の障害が 大きい程夕ッピング可能回数は少なくなり, 毎秒 2 回 および 3 回のタッピングが行えない場合, 咀嚼障害の 存在を推定できると考えられた.

咀嚼筋の sp 出現のメカニズムについて, 虫本は, 機 能的咬合系のすべての感覚受容器からのフィードバッ クが関与し, それらが相互に関連しあって変動し, 感 覚受容器として（1）歯根膜受容器, (2) 筋紡錘, (3) Golgi 腱器官, があり, さらに歯根膜の機械的刺激, 歯肉の電気的刺激により sp は発現するが, spの神経 生理学的考察はきわめてむずかしい31) と述べている. また sp の出現は, 咀嚼筋活動の抑制と興奮, つまり開 口反射成分と閉口反射成分のいずれもの関与が否定で きず, 円滑な咀嚼運動の遂行にとって重要である31) と も述べており, sp 出現を調査する事は労災による咀嚼 障害の原因である顎口腔機能の生理学的異常を把握す るのに有用であると思われた。

労災患者のタッピング運動時の sp 出現率はタッピ ング頻度が早くなると sp 出現率が低くなった。これ は, いわゆる正常咬合を有するものでは毎秒 3 回のタッ ピング運動において sp 出現率は最も安定している25)
との報告とは異なる所見であった. sp 出現率は, 可能 率 I の患者において毎秒 1 回のタッピングで 69.8\%, 2 回で $65.2 \%, 3$ 回で $60.3 \%$, 以下咀嚼可能率の低下 とともに, sp 出現率も漸減した。これは, 正常咬合者 のタッピング運動時の sp 出現率は $90 \%$ 前後であ

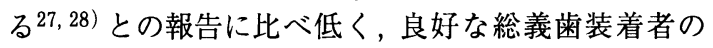
sp 出現率の $72 \%{ }^{29)}$ に近い值であった.

Eichner 分類 B-4 および C の症例の毎秒 1,2 お よび 3 回のタッピング運動時の sp 出現率は, A, B$1, \mathrm{~B}-2$ および $\mathrm{B}-3$ の症例に比べ低かった $(\mathrm{P}<0.05) . \mathrm{sp}$ 出現率 $50 \%$ 以上と未満に分けてみると， $50 \%$ 未満の患者で咀嚼可能率が低く $(\mathrm{p}<0.01), \mathrm{sp}$ 出 現率の低下は咀嚼障害と何らかの関連があると考えら れた.しかし, 毎秒 1 回のタッピング時に sp 出現率が $20 \%$ 末満であった 7 例中 2 例は, 可能率 V, Eichner 分類は A と, 歯の所見と咀嚼筋筋電図所見および咀嚼 可能率との間に大きな相違があり，咀嚼障害を sp の 出現率から評価することは困難であると考えられた。

咬合接触面積および咬合力を計測するために用いた デンタルプレスケールは以前から歯科領域の研究に応 用されてきた 32 35) が，その解析システムは開発され ていなかった。しかし，今回，専用解析システム OCCLUZER が開発され，（1）咬合力バランス，（2） 咬合力分布, (3) 咬合力左右バランス, (4) 咬合力ヒ ストグラム, 等を分析することが可能となった。すで に30H, $50 \mathrm{H}$ および解析装置を用いた歯列の咬合接触 面積, 咬合力についての報告36 48) が行われている. その中の鈴木らの報告 ${ }^{39)}$ では, 咀嚼能力とデンタルプ レスケールによる咬合所見との間に関連があることを 示唆しており, 鈴木らは従来の方法では十分には解明 できなかった天然歯と義歯, 天然歯とインプラントな ど, 咬合圧の負担能力の異なるものが混在する口腔内 においても, 本システムを用いることにより咬合バラ ンスなどについて新たな指針が見い出しうる39）と述 べている. 労災患者では対象の年齡分布は幅広く，歯 の所見も天然歯列から種々の補綴物が混在するものま でさまざまであり,さらに外傷による咬合不全, 知覚 異常, 顎運動障害等, 咀嚼能力に変化をおよほすと考 えられる因子が多く, 労災患者の咀嚼能力の評価には, 歯列全体の咬合所見を観察できるデンタルプレスケー ルは有用であると考えた。

プレスケールによる咬合所見を労災患者と健常者で 比較すると, 健常者の $30 \mathrm{H}$ の測定では, 荒木らの接触 面積の平均は $44.2 \mathrm{~mm}^{2}$, 平均咬合力は $10.0 \mathrm{MPa}$, 総咬 合力は $431.3 \mathrm{~N}$, 有効率は 86.6\%で各項目に左右差は認 めないとの報告 41,42$)$ と一致した.また, $50 \mathrm{H}$ では服部 らの全咬合力に占める左右差の割合は正常者では 9.3 $\pm 6.7 \%$ ，顎関節患者では $16.3 \pm 11.0 \%{ }^{36,38)}$ ，木村らの 正常者の総咬合力の平均は約 $800 \mathrm{~N}$ 程度 ${ }^{47)}$ であったと の報告とほほ同様であった. 労災患者は健常者に比べ 
$30 \mathrm{H}$ による接触面積および総咬合力, $50 \mathrm{H}$ による接触 面積, 最大咬合力および総咬合力の平均は小さく, 最 低值は著しく小さく, 接触面積および総咬合力の左右 差の平均值は大きく, 最高值はさらに大きかった。こ れは T-SCAN システムでの咬合力バランスは健常 者ではほぼ左右対称であるが, 顎機能異常者では左右 の咬合接触に差が認められ，咬合接触力が弱いとの鍋 島ら ${ }^{49)}$ の報告に一致した。

$50 \mathrm{H}$ による咬合所見のうち, 最大咬合力と咀嚼可能 率の相関係数は 0.60 であり, 可能率 I では最大咬合力 が $120 \mathrm{MPa}$ を越えたものが存在したが, 可能率II お びIIIでは 1 例もなく, 鈴木らのデンタルプレスケール で測定された最大咬合力が大きいほど咀嚼能力が高く

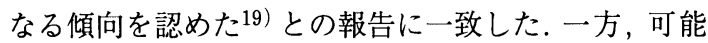
率 $\mathrm{V}$ およびV の中には最大咬合力が $120 \mathrm{MPa}$ を超過 したものがあり, 鈴木ら ${ }^{39)}$ の報告と一致しない症例を 認めた。

$30 \mathrm{H}$ と $50 \mathrm{H}$ を比べると測定可能最大咬合力が 13 $\mathrm{MPa}$ と $120 \mathrm{MPa}$ と性能に差があり, 両者の計測值の 比較は意味を持たない. 今回の労災患者の計測結果で は, $30 \mathrm{H}$ では有効率が平均 $84.9 \%$ と $50 \mathrm{H}$ の $99.5 \%$ に比 べ低く, 30H では計測範囲を超過している部分が大き く，咬合力の測定には不向きであると考えられた. $30 \mathrm{H}$ では接触面積が $50 \mathrm{H}$ に比べ大きかったが, この原 因は, $30 \mathrm{H}$ が $50 \mathrm{H}$ では検出しない $3 \sim 5 \mathrm{MPa}$ の圧力 で発色を起こすことが原因の一つと考えられた．鈴木 $ら^{40)}$ がいうように咬頭嵌合位における咬合力を測定 しょうとする場合, 咬頭嵌合位にいたるまでに滑走が ともなうと実際より大きな值が表示される可能性が高 く, 特に低圧用の $30 \mathrm{H}$ ではその影響が強いと指摘して いる. 本研究の結果では労災患者の咀嚼可能率は $30 \mathrm{H}$ による接触面積との相関が強く，咬頭嵌合位にいたる までの滑走が咀嚼能力と関係していることが推察され， $30 \mathrm{H}$ でも接触面積を計測する必要性が示唆された。

服部らによると，正常有歯顎者においては，両側大 臼歯の全咬合力に占める割合は 85.9 93\%に及ぶと報 告38)されている.上下第一, 第二大臼歯の咬合歯数と 咀嚼可能率の関係についてみると, 1 歯でも咬合して いるものは, 1 歯も咬合していないものに比べ咀嚼可 能率は高く $(\mathrm{p}<0.05)$ ，また $30 \mathrm{H}$ による接触面積も大

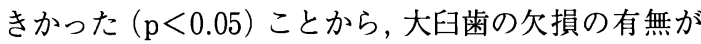
咀嚼障害の大きな要因であることが示唆された.

多変量解析の結果から咀嚼可能率は, 毎秒 3 回規定 時の実際のタッピング回数, 大臼歯咬合歯数, デンタ ルプレスケール $30 \mathrm{H}$ による接触面積の左右差, および $50 \mathrm{H}$ による最大咬合力，により説明が可能であった． 咀嚼可能率を推定する式より算出された咀嚼可能率の 予測値と実測值を比較すると, 咀嚼可能率のランクが 異なったものは 25 例中 5 例であった。このうち予測 值でのランクが高かったものが 4 例, 低かったものは
1 例であった. その内容をみると, 実測值が可能率 II で予測值では I であったもの 2 例, 実測值は III で予測 值では II であったもの 1 例, 実測値はVで予測值が III であったものが 1 例みられた。一方，実測值は正で予 測值はIV と低かったものが 1 例あった．すなわち，咀 嚼可能率 $40 \%$ 以上の症例の中にも問診調查から得ら れた可能率が，他覚所見から得られる予測值と異なる 場合があることを示している. それゆえ労災患者にお いては, 問診調査から得られた咀嚼可能率をそのまま, その患者の咀嚼能力として評価せず, 他覚所見からの 予測值を併せて算定し, 総合的に評価を行う必要があ ると思われた. また，この評価に際しては，特にデン タルプレスケールによる咬合所見が重要であることが 示唆された.一方, この 25 例中可能率 $\mathrm{V}$ および $\mathrm{V}$ の症 例は 3 例のみであり, 可能率 $\mathrm{V}$ の 2 例では実測值と予

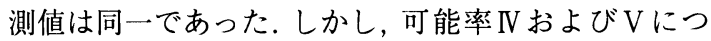
いては症例数が少なく十分な検討はできなかった.

歯の損傷の評価は, 現行法のもとでは補償が亦失歯 数により評価されているので, 受けた障害に対する補 償という観点からは亦失歯数は重要である。しかしな がら労災患者の咀嚼能力を評価するという観点に立つ と, 袈失歯数よりも, 残存歯の歯種, 歯の抵抗得点, 咬 合状態，あるいはプレスケールによる咬合所見等から， 総合的に評価する方が妥当であると考えられた。

\section{結語}

（1）労働災害による咀嚼障害認定のための意見書 作成を求め来院した 51 名の患者に対し，歯の所見，下 顎運動所見, 咀嚼筋筋電図所見, デンタルプレスケー ルによる咬合所見, 咀嚼可能食品の問診から算定した 咀嚼可能率を調査した

(2) 咀嚼可能率 $40 \%$ 以上では, 咀嚼可能率の減少 とともに歯の障害は漸増し, 開口量は漸減した。

(3) 咀嚼可能率 $40 \%$ 以上では, 咀嚼可能率の低下 とともに sp 出現率, タッピング可能回数は漸滅した.

（4）咀嚼可能率 $40 \%$ 以上では, 咀嚼可能率の減少 とともに, $30 \mathrm{H}$ での接触面積, 総咬合力は漸減, その 左右差は漸増, $50 \mathrm{H}$ での接触面積, 総咬合力, 最大咬 合力は漸隇, その左右差は漸増した。

(5) 咀嚼可能率と各調査項目の間には咀嚼可能率 $40 \%$ 以上では相関関係が認められ，咀嚼可能食品問診 調査と各調査項目の所見がほぼ一致していたことが示 された。

(6) 咀嚼可能率 $40 \%$ 未満については本研究では症 例数が少なく，咀嚼障害の評価を十分に行えなかった。

（7）労災患者の咀嚼能力の評価においては, 残存 歯の歯種や咬合状態をもとに評価を行うことが妥当で あり, 咬合状態を評価するにあたって，デンタルプレ スケールによる咬合所見は特に有用であった。 
稿を終えるに当たり, 本研究に際して終始ご懇篤なる ご指導とご校閲を賜りました鶴見大学歯学部瀬戸晥一教 授に深甚なる謝意を表します。またご専攻の立場から御 懇篤なるご教示をいただきました鶴見大学歯学部石橋克 禮教授, 福島俊士教授に心より深謝するとともに種々の 御助力御助言をいただきました富士写真フィルム（株） 情報記録紙部来生博氏に感謝の意を表します。

本論文の要旨は, 第 41 回日本災害学会 (1993 年 9 月 日, 札幌), 第 40 回日本口腔外科学会 (1995 年 10 月曰日, 東京）において報告した。

\section{引用 文 献}

1）労働省労働基準局監修: 労災補償, 障害認定必 携. 第 2 版, 労働福祉共済会, 東京, 1981, 15-65 頁.

2) Eichner, K.: Über eine Gruppeneinteilung der Lückengebisse für die Prothetik. Dtsch Zahnarztl Z 10: 1831-1834 1955.

3) 内山洋一 : ブリッジの適応症と設計. 補緅誌 38: 929-936 1994.

4）古屋良一：限界運動路の分析. 石岡靖監修; 頡 口腔機能分析の基礎とその応用一 $\mathrm{ME}$ 機器をい かに臨床に活かすか一. 第 1 版, デンタルダイ ヤモンド社, 東京, 1991, 54-65 頁.

5）柳沢幸江, 田村厚子, 他：食品の物性と摂食機 能に関する研究 第 1 報 食品物性の器機的測 定, 並びに食品分類について. 小児歯科学雑誌 23: 962-983 1985.

6）船越正也：咀嚼の成立と障害の生理的意義. 歯 界展望 76: 45-49 1990 .

7）大塚純正 : 咀嚼障害の臨床的測定法の開発. 歯 界展望 76: 362-365 1990.

8）石原寿郎：篩分法による咀嚼能率の研究. 口病 誌 22: 207-255 1955.

9）増田元三郎, 藤山真正, 他：ATP 顆粒剂を用い た吸光度法による新しい咀嚼能力測定法 第 1 報 測定方法と試料としての ATP の性質につ いて. 口科誌 30: 103-110 1981.

10）加藤光雄, 斉藤光彦, 他 : 咀嚼機能の評価方法 について. 補緅誌 31: 1506-1513 1987.

11）加藤光雄, 笛木賢治, 他 : 多変量解析を応用し た咀嚼粉砕能力の評価方法について．補緅誌 39: 165-170 1995.

12）山本為之：総義歯臼歯部人工歯の配列について (その 2 ) 一特に反対咬合について一. 補綴臨床 5 : 395-400 1972 .

13）松浦正朗, 野村隆祥, 他：義顎装用者の簡単な 咀嚼能の測定法について. 顎顔面補緅 $4: 52-58$ 1981.

14）佐藤裕二, 石田栄作, 他 : 総義歯装着者の食品 攝取状況. 補緅誌 32: 774-779 1988.

15）平井敏博, 安斉 隆, 他: 捸取可能食品アンケー 卜を用いた全部床義歯装着者用咀嚼機能判定表 の試作. 補綴誌 32: 1261-1267 1988.
16）越野 寿, 高崎英仁, 他：下顎骨連続離断術後 の下顎顎義歯とその咀嚼機能評価. 東日本歯学 雑誌 $7: 99-1101988$.

17）内田達郎 : 全部床義歯による咀嚼能力の評価に 関する研究一咀嚼能力に影響する因子と評価に 適した食品の検討一. 口病誌 58: 182-197 1991.

18）幸阪保雄, 加藤光雄, 他 : 部分床義歯装着によ る咀嚼能力ならびに銁歯動摇度の経時的変化 補綴誌 35: 681-688 1991.

19）鈴木哲也, 熊谷 宏, 他 : 高齢者の咬合支持状 況に関する研究. 補緅誌 38: 476-484 1993.

20）後藤真人, 石井拓男, 他: 成人歯科保健の指標 としての「噛めかた」の検討 第 2 報 年齢別 喪失歯数別検討. 口腔衛生学会雑誌 37: 444-445 1987.

21) 平野浩彦, 石山直欣, 他 : 地域老年者の咀嚼能 力および口腔内状況に関する研究 第 2 報 咀 嚼能力と口腔内状況および身体状態との関連に ついて. 老年歯学 7:150-155 1993.

22) Szentpetery, A.: Clinical utility of mandibular movement ranges. J Orofac Pain 7 : 163-168 1993.

23）野首孝祠, 吉田 実, 他：バイトプレーンの装 着が咀嚼筋筋電図に及ほす影響, 第 1 報 タッ ピング運動時の筋活動について. 補綴誌 33 : 323-336 1989 .

24）藤井弘之：タッピング（tapping）運動. 石岡 靖監修; 顎口腔機能分析の基礎とその応用一 ME 機器をいかに臨床に活かすか一. 第 1 版, デンタルダイヤモンド社, 東京, 1991, 78-87 頁.

25）小松義典, 小林義典 : 咀嚼系機能障害の筋電図 学的診断に関する研究. 歯学 72: 313-367 1984.

26）山鹿卓郎 : 咀嚼筋筋電図分析による顎口腔系機 能異常診断とその臨床応用に関する研究. 補緅 誌 27: 50-73 1983.

27）新谷明幸, 須川洋一, 他 : 歯牙タッピング時の 衝撃加速度と咬筋 silent period. 額機能 2 : 99-104 1984.

28）小川晴彦 : 実験的咬合干渉が咀嚼筋筋電図の時 間的要素におよほす影響. 歯科医学 39: 421-440 1976.

29）近藤修六 : 全部床義歯の予後判定に関する筋電 図学的研究一主としてタッピング時における Silent Period と咬合音を基準とした咬合状態 との関係に関する考察—. 補経誌 30: 1121-1135 1986.

30）長澤 亨, 津賀一弘, 他 : 若年者と高齢者のタッ ピングの頻度. 補緅誌 34: 197-201 1990.

31）虫本栄子: 咀嚼筋の silent period. 石岡靖監 修; 喕口腔機能分析の基礎とその応用一 $\mathrm{ME}$ 機 器をいかに臨床に活かすか一. 第 1 版, デン夕 ルダイヤモンド社, 東京, 1991, 198-207 頁.

32）福島俊士, 戸代原孝義, 他 : 圧力測定用シート 「プレスケール」に関する基礎的研究. 補綴誌 24: 337-344 1980. 
33）二川芳人, 牧田 亨, 他 : プレスケール の歯科 領域への応用について.日本歯科評論 448: 921001980.

34）福田光男 : 新しい咬合力測定システムについて一 ニュープレスケールとその測定装置について一. 日歯周誌 23: 397-414 1981.

35）木下四郎, 野口俊英, 他 : 咬合の診査・記録の ための新しい方法一オックルーザルプレスケー ル®について一. 歯界展望 59: 311-320 1982.

36）服部佳功, 渡辺 誠 : 咬合力測定法に関する最 近の進歩. 歯界展望 85: 657-668 1995.

37) 渡辺誠, 服部佳功: Dental Prescale 50 を 用いた咬合診断とその臨床応用一主に咬合力の 強さを指標とした咬合診査法について一。歯界 展望 84: 109-126 1994 .

38）服部佳功, 奥川博司, 他 : Dental Prescale を 用いた歯列における咬合力測定. 補綴誌 38 : 835-841 1994 .

39）鈴木哲也, 熊谷 宏, 他 : 咬合圧測定システム の臨床応用に関する研究. 口病誌 61: 437-445 1994.

40）鈴木哲也, 渡邊竜登美, 他 : 感圧シートを用い た新しい咬合圧測定システムの有用性. 補綴誌 38: 966-973 1994.

41）荒木章純, 伊藤 裕, 他：新しい咬合評価シス テム（デンタルプレスケール OCCLUZER）の 臨床応用に関する一考察. 歯界展望 84: 100710191994 .

42) 荒木章純, 伊藤 裕, 他 : 新しい咬合診査機器
(Occluzer FPD703) による咬合の評価 その 1 正常者の習慣性閉口位について. 日本歯科 評論 624: 187-194 1994.

43）苗代 明, 沼部幸博, 他 : イニシャルプレパレー ション前後における咬合力の変化に関する研究 一第 1 報 スケーリング・ルートプレーニング 処置前後の変化について一. 日歯周誌 36: 9029111994.

44）鴨井久一, 苗代 明, 他 : デンタルプレスケー ルシステムの歯周病診査への応用 オクルーザー FPD703 を用いた動摇歯の回復度チェック．日 本歯科評論 625: 183-194 1994 .

45）緒方哲朗, 峰松清仁, 他 : デンタルプレスケー ルを用いた小児の咬合接触状態解析の再現性に 関する研究. 小児歯科学雑誌 32: 480-487 1994.

46）中田 稔, 緒方哲朗, 他 : デンタルプレスケー ルの小児歯科における臨床応用. 歯界展望 85 : 239-246 1995 .

47）木村朋義, 佐藤華織, 他：「デンタルプレスケー ル」を用いた咬合接触圧の測定一咬合接触圧の 左右比に関する検討一. 北海道歯誌 16: 12-19 1995.

48）熊谷 宏, 鈴木哲也, 他 : 咬合力の分布を考慮 した全部床義歯装着者の咬合診査. 歯界展望 86: 233-240 1995.

49）鍋島史一, 田中昌博, 他: T-SCAN システムか らみた咬頭嵌合位での咬合接触バランスについ て. 補緅誌 34: 340-349 1990. 